\title{
Analisis Hukum Terhadap Amandemen Asean Protocol On The Enhanced Dispute Settlement Mechanism
}

\author{
Dwi Astuti Nurjanah \\ Magister Ilmu Hukum, Universitas Indonesia \\ Email: dwiastuti.nurjanah@gmail.com
}

\begin{abstract}
Abstrak. berlakunya ketentuan Enhanced Dispute Settlement Mechanism (EDSM) yang dideklarasikan oleh ASEAN pada tahun 2004, kemudian diamandemen dalam ASEAN Protocol on Enhanced Dispute Settlement Mechanism pada tahun 2019 yang diadopsi oleh Negara-negara anggota ASEAN yang mengatur tentang penyelesaian sengketa. Berdasarkan ketentuan tersebut, salah satunya yang terlihat nyata dapat dilihat dalam praktik mekanisme penyelesaian sengketa sangat menitikberatkan konsultasi tertulis yang menunjukkan dasar hukum pengaduan dan Senior Economic Officials Meeting (SEOM) sebagai lembaga pengajuan permintaan untuk konsultasi. Fokus Permasalahan dalam penulisan jurnal ini yaitu menganalisa isu permasalahan bahwa ASEAN EDSM lazimnya diketahui sebagai mekanisme yang tidak pernah digunakan oleh ASEAN, serta prospek bagi negara-negara ASEAN untuk menggunakan mekanisme penyelesaian sengketa tersebut di masa depan dengan adanya amandemen EDSM di tahun 2019, dan bagaimana Negaranegara anggota ASEAN akan mengadopsi amandemen dari Protokol ASEAN ESDM ini. Hasil dari penelitian ini menunjukan bahwa mekanisme penyelesaian sengketa yang mungkin akan terjadi dalam proses implementasi protokol ESDM pada sektor ekonomi dan perdagangan internasional harus lebih diperjelas. Pengikatan atau kewajiban yang disepakati dalam amandemen Protokol EDSM yang baru memperkuat mekanisme penyelesaian sengketa Perdagangan ASEAN untuk mencapai efisiensi dengan cara meningkatkannya menjadi praktis, transparan dan jelas.
\end{abstract}

Kata Kunci : EDSM, Penyelesaian Sengketa, ASEAN.

Abstract. the enactment of the provisions of the Enhanced Dispute Settlement Mechanism (EDSM) declared by ASEAN in 2004, then amended in the ASEAN Protocol on Enhanced Dispute Settlement Mechanism in 2019 which was adopted by ASEAN member countries which regulate dispute settlement. Based on these provisions, one of the obvious ones can be seen in the practice of the dispute settlement mechanism emphasizing written consultation showing the legal basis for complaints and the Senior Economic Officials Meeting (SEOM) as an institution for submitting requests for consultation. The focus of the problem in writing this journal is to analyze the issue of problems that ASEAN EDSM is generally known for as a mechanism that has never been used by ASEAN, as well as the prospects for ASEAN countries to use the dispute settlement mechanism in the future with the EDSM amendment in 2019, and how ASEAN member countries will adopt this amendment to the ASEAN ESDM Protocol. The results of this study indicate that the dispute settlement mechanisms that may occur in the process of implementing the EMR protocol in the economic sector and international trade must be clarified. The binding or obligation agreed in the new EDSM Protocol amendment strengthens the ASEAN Trade dispute settlement mechanism to achieve efficiency by increasing it to be practical, transparent and clear.

Keywords : EDSM, Dispute Settlement, ASEAN.

\section{PENDAHULUAN}

Piagam ASEAN merupakan badan hukum internasional yang dibentuk dalam rangka untuk memelihara dan meningkatkan

Jurnal Ilmu Sosial dan Pendidikan perdamaian, keamanan dan stabilitas serta lebih memperkuat nilai-nilai berorientasi perdamaian di kawasan. Suatu organisasi yang berlandaskan aturan tentunya perlu 
memiliki prosedur atau mekanisme penyelesaian sengketa dalam rangka pemenuhan hak dan kewajiban setiap negara anggotanya, secara khusus untuk menyelesaikan sengketa yang terjadi antar negara anggota ASEAN itu sendiri. Disebutkan pula bahwa ASEAN adalah sebuah komunitas, bukan sekedar sekelompok negara yang dilingkupi oleh kedekatan geografis. ASEAN merupakan suatu organisasi regional yang tertutup (closed regional organization) karena keanggotaannya tidak terbuka untuk kelompok negara-negara lainnya.

Sejak awal berdirinya, ASEAN bertujuan mempercepat pertumbuhan ekonomi, kemajuan sosial dan pengembangan budaya. Dalam perkembangannnya, kerjasama ekonomi ASEAN memerlukan suatu mekanisme yang lebih baik dengan dilaksanakannya Konferensi Tingkat Tinggi yang selanjutnya disebut KTT ASEAN I dan II di Bali pada tahun 1976 dan di Kuala Lumpur (1977) yang membahas agar ASEAN memperkuat solidaritas politik dalam hubungan kerjasama ekonomi dengan menumbuhkan pandangan yang selaras. Selanjutnya, pada tahun 1992 diadakan KTT ASEAN IV bertempat di Singapura, telah menandatangani Framework Agreement on Enhancing ASEAN Economic Cooperation yang menjadi dasar terebentuknya kerjasama dalam bidang ekonomi sekaligus menandai dicanangkannya AFTA pada tanggal 1 Januari 1993 dengan Common Effective Preferential Tariff (selanjutnya disebut CEPT).

Pendirian AFTA memberikan implikasi dalam bentuk pengurangan dan eliminasi tarif, penghapusan hambatan-hambatan nontarif, dan perbaikan terhadap kebijakankebijakan fasilitasi perdagangan. Dalam perkembangannya, AFTA tidak hanya difokuskan pada liberalisasi perdagangan barang, tetapi juga investasi.

Terkait dengan penyelesaian sengketa kerjasama ekonomi antar negara anggota ASEAN telah diatur Framework Agreement on Enhancing ASEAN Economic Coorperation Pasal 9, dinyatakan bahwa:

Jurnal Ilmu Sosial dan Pendidikan
"Any differences between the Member States concerning the interpretation or application of the agreement or any agreements arising thereform shall, as far as possible, be settled amicably between the parties. Whenever necessary, an appropriate body shall be designated for the settlement or disputes."

Negara-negara anggota ASEAN yang terlibat dalam suatu sengketa lebih memilih untuk menggunakan lembaga lain di luar mekanisme institusional yang terdapat di dalam ASEAN. Kesadaran akan penyelesaian sengketa telah ada di tahun 1971 yang tertuang dalam Declaration on the Zone Peace, Freedom and Neutrality (selanjutnya disebut ZOPFAN) kemudian dilanjutkan dalam Declaration of ASEAN Concord 1976 dimana negara anggota berkomitmen untuk melaksanakan settlement of intraregional disputes. Atas dasar itu dibuatlah tiga mekanisme utama penyelesaian sengketa di ASEAN yaitu Treaty of Amity and Cooperation in Southeast Asia (selanjutnya disebut TAC 1976), Protocol on Dispute Settlement Mechanism 1996 dan Protocol for Enhanced Dispute Settlement 2004 dan amandemen 2019. Ketiga mekanisme tersebut masih lemah dengan melihat deklarasi ASEAN 1967 sebagai landasan hukum terbentuknya instrumen.

Kemudian, ASEAN Member Countries (AMCs) bermaksud untuk membentuk ASEAN Community 2015 (AC15) yang terdiri dari tiga pilar yaitu ASEAN Political Security Community (APSC), ASEAN Economic Community (AEC), dan ASEAN SocioCultural Community (ASCC). Di antara tiga pilar tersebut, MEA bisa dikatakan sebagai inti dari kesepakatan. Memiliki empat karakteristik yaitu, pasar tunggal dan basis produksi, kawasan ekonomi yang berdaya saing tinggi, kawasan pembangunan ekonomi yang merata, dan kawasan yang terintegrasi penuh ke dalam perekonomian global. Kawasan ASEAN tidak akan ada hambatan perdagangan, hambatan tarif dan hambatan non tarif ekonomi kawasan. Anggota mengadopsi cetak biru MEA untuk mencapai 
kawasan ekonomi yang sangat kompetitif, dengan barang, jasa, investasi, tenaga kerja terampil, dan modal yang mengalir bebas. Dengan kata lain, integrasi ekonomi ASEAN telah menekankan perlunya regionalisme terbuka lebih dari pengelompokan ekonomi regional lainnya, pangsa interaksi perdagangan dan investasi ASEAN adalah ekstra-regional. Ini adalah ekspresi dari strategi pembangunan ASEAN.

Terdapat beberapa tantangan yang dihadapi ASEAN dalam mencapai tujuannya, antara lain masih kurangnya mekanisme pemantauan untuk memastikan pelaksanaan yang efektif, identifikasi prioritas perjanjian ASEAN, untuk setiap periode dan badan pelaksana, serta meningkatkan koordinasi antar pilar, sebagai serta mobilisasi sumber daya. Sementara kemajuan telah dibuat dalam menurunkan tarif dan beberapa hambatan ekonomi di balik perbatasan, hambatan nontarif tetap menjadi hambatan utama untuk mencapai pasar tunggal pada tahun 2025. Liberalisasi perdagangan jasa juga berjalan lambat meskipun Industri ini semakin penting di kawasan. Semua masalah ini akan menjadi akar perselisihan antar AMC dalam mencapai tujuan MEA. Berdasarkan Piagam ASEAN, sengketa perdagangan harus diselesaikan sesuai dengan ASEAN Protokol tentang Mekanisme Penyelesaian Sengketa yang Ditingkatkan tahun 2004 (Protocol Vientiane).

\section{Rumusan Masalah}

Berdasarkan fakta yang telah dipaparkan di atas, penulis merasa perlu untuk melakukan penulisan artikel ilmiah dengan judul Analisis Hukum Terhadap Amandemen Asean Protocol On The Enhanced Dispute Settlement Mechanism. Dengan fokus pada rumusan permasalahan : bagaimana prospek bagi negara-negara ASEAN untuk menggunakan mekanisme penyelesaian sengketa tersebut di masa depan dengan adanya amandemen EDSM di tahun 2019 ?, ASEAN EDSM lazimnya diketahui sebagai mekanisme yang tidak pernah digunakan oleh ASEAN dan bagaimana Negara-negara anggota ASEAN akan mengadopsi amandemen dari Protokol ASEAN ESDM ini ?

\section{Tujuan dan Manfaat Penelitian}

1. Tujuan Penelitian

Penelitian ini bertujuan untuk mengetahui, menganalisis dan memahami prospek bagi negara-negara ASEAN untuk menggunakan mekanisme penyelesaian sengketa tersebut di masa depan dengan adanya amandemen EDSM di tahun 2019 dan mengadopsi amandemen dari Protokol ASEAN ESDM ini.

2. Manfaat Penelitian

Penelitian ini mempunyai manfaat teoritis dan praktis. Secara teoritis penelitian ini diharapkan memberikan kontribusi dalam perkembangan ilmu pengetahuan hukum, terutama bidang penyelesaian sengketa internasional. Sedangkan secara praktis, hasil penelitian ini dapat digunakan sebagai sumber kajian ilmu pengetahuan bagi masyarakat umum pada umumnya dan kepada akademisi pada khususnya.

\section{HASIL PENELITIAN DAN PEMBAHASAN \\ ASEAN Way Sebagai Cara ASEAN Menghadapi Berbagai Sengketa}

Mekanisme kerjasama dan penyelesaian konflik di kawasan Asia Tenggara yang dilandasi prinsip non intervency diplomacy, saling menghormati, konsensus, dialog dan konsultasi, juga larangan penggunaan kekerasan bersenjata itu disebut sebagai ASEAN Way. Ditambahkan pula oleh Narine bahwa ASEAN way mengutamakan pengaturan dan implementasi nasional dibandingkan penciptaan otoritas supranasional.

Pada tahun 1971 ASEAN way yang ditetapkan dalam TAC kembali ditegaskan oleh ASEAN. Pada tahun ini ASEAN menyatakan diri sebagai wilayah damai, bebas, dan netral. ASEAN merupakan The Zone of Peace, Freedom, and Neutrality (ZOPFAN). Kebebasan dalam ZOPFAN dimaksudkan sebagai kebebasan yang berhak diperoleh oleh setiap anggota untuk tidak diintervensi mengenai permasalahan domestik mereka. Intervensi disini bisa diartikan dalam 
hal kemerdekaan atau independensi serta integritas negara itu sendiri. Intervensi akan mengganggu kebebasan, kemerdekaan dan integritas ASEAN yang menginginkan netralitas di regionalnya.

ASEAN Way semakin memperoleh kekuatan ketika dinyatakan lagi dalam ASEAN Charter. Piagam ASEAN menyebutkan bahwa ASEAN dilandasi prunsip-prinsip utama sebagai berikut:

a. menghormati kemerdekaan, kedaulatan, kesetaraan, integritas wilayah, dan identitas nasional seluruh Negara anggota ASEAN;

b. tidak campur tangan urusan dalam negeri negara anggota ASEAN;

c. penghormatan terhadap hak setiap negara anggota untuk menjaga eksistensi nasionalnya bebas dari campur tangan eksternal, subversi, dan paksaan;

d. menghormati kebebasan fundamental pemajuan dan perlindungan HAM, dan pemajuan keadilan sosial;

e. menjunjung tinggi piagam $\mathrm{PBB}$ dan hukum internasional termasuk hukum humaniter yang telah disetujui oleh negara anggota ASEAN;

f. tidak turut serta dalam kebijakan atau kegiatan apapun termasuk penggunaan wilayahnya, yang dilakukan Negara anggota atau nonanggota ASEAN atau subyek negara manapun yang mengancam kedaulatan, integritas wilayah, atau stabilitas politik dan ekonomi negaranegara anggota ASEAN.

Di samping prinsip-prinsip di atas, ASEAN Way juga dirumuskan dalam Pasal 2 (e) Piagam ASEAN yang menetapkan bahwa kerjasama negara-negara anggota ASEAN dilandasi prinsip non intervensi urusan dalam negeri anggotanya.

Dari sisi fungsional, ada empat kewajiban yang harus dipatuhi setiap negara anggota ASEAN sebagai konsekuensi dari keberadaan prinsip non intervensi, yaitu:

a. Pantangan untuk mengkritisi tindakan apapun dari satu negara anggota terhadap warga negaranya, termasuk pelanggaran terhadap hak-hak asasi manusia, serta membuat keputusan mengenai

Jurnal Ilmu Sosial dan Pendidikan keanggotaan suatu negara berdasarkan sistem atau bentuk pemerintahannya;

b. Mengkritisi tindakan dari satu Negara yang melanggar prinsip nonintervensi;

c. Menolak pengakuan (recognition), permohonan suaka, ataupun bentuk dukungan lainnya terhadap kelompok pemberontak yang mengganggu kestabilan nasional negara tetangga;

d. Menyediakan dukungan politis dan bantuan materi untuk negara yang sedang berkampanye menentang kegiatankegiatan subversif yang mengganggu stabilitas negara.

Lebih lanjut, Pasal 20 (1) ASEAN Charter menekankan bahwa pengambilan keputusan berdasarkan prinsip konsultasi dan konsensus. Satu catatan penting yang merupakan perkembangan baru dalam ASEAN Way tercantum dalam Pasal 21. Pasal ini menyatakan bahwa apabila berkaitan dengan implementasi komitmen di bidang ekonomi maka Pasal 21 (2) memungkinkan diterapkannya ketentuan yang lebih fleksibel. Apa yang ditetapkan dalam Pasal 21 ini sesungguhnya merupakan penegasan dari Enhanced Dispute Settlement Mechanism (EDSM) yang dideklarasikan oleh ASEAN pada tahun 2004, kemudian diamandemen dalam ASEAN Protocol on Enhanced Dispute Settlement Mechanism pada tahun 2019, yang merasakan tidak adanya jaminan atau lemahnya pelaksanaan komitmen kerjasama bidang ekonomi akibat kuatnya prinsip kedaulatan negara di organisasi mereka. Namun demikian ini hanya berlaku untuk bidang ekonomi saja, tidak untuk bidang yang lain seperti terjadinya kekerasan atau pelanggaran HAM di suatu negara ASEAN.

1. Penjabaran Analisa Amandemen ASEAN Protocol on The Enhanced Dispute Settlement Mechanism (ASEAN EDSM 2019) Sebagai Mekanisme Penyelesaian Sengketa

Pasal 3 Amandemen ASEAN Protocol on The Enhanced Dispute Settlement Mechanism 2019 (EDSM), langkah wajib pertama harus dimulai dengan konsultasi tertulis yang menunjukkan dasar hukum 
pengaduan. Kemudian, Senior Economic Officials Meeting (SEOM) akan memberi tahu pengajuan permintaan untuk konsultasi. Negara Anggota yang memiliki keuntungan secara langsung atau tidak dapat membuat pernyataan atau proposal kepada Negara Anggota yang bersangkutan dan harus dipertimbangkan. Kemudian, pihak lain harus menjawab dalam waktu 10 hari setelah tanggal penerimaan permintaan, konsultasi diadakan dalam jangka waktu 30 hari setelah tanggal penerimaan permintaan. Protokol mengizinkan para pihak yang bersengketa setiap saat dapat menyetujui atau menghentikan tiga mekanisme lain yaitu jasa baik, konsiliasi dan mediasi tergantung pada permintaan pihak tersebut.

Pasal 4 EDSM, setelah prosedur untuk jasa baik, konsiliasi atau mediasi dihentikan, pihak pengadu kemudian dapat melanjutkan permintaan kepada SEOM untuk pembentukan panel.

Pasal 5 EDSM, menetapkan panel harus dibentuk SEOM, kecuali SEOM memutuskan dengan konsensus untuk tidak membentuk panel. Jika konsultasi gagal, pengadu dapat mengajukan perselisihan ke SEOM dalam waktu 45 hari setelah penerimaan permintaan dan sirkulasi. Panel akan terdiri dari tiga atau lima panelis tergantung pada kesepakatan para pihak. Lampiran II Protokol, menetapkan bahwa pemilihan mereka yang memenuhi syarat untuk menjadi anggota panel harus memiliki kualifikasi:

1. Perorangan pemerintah dan/atau nonpemerintah yang berkualifikasi baik;

2. Profesional hukum atau akademisi di bidang hukum perdagangan internasional dan perjanjian ekonomi ASEAN.

Sekretariat ASEAN bertanggung jawab untuk mendaftarkan individu yang memenuhi syarat dapat ditarik anggota panel. Daftar harus menunjukkan pengalaman atau keahlian khusus.

Pengadilan telah mengadopsi aturan prosedurnya berdasarkan mutatis mutandis berdasarkan Fasilitas Tambahan ICSID untuk Administrasi Proses Konsiliasi, Arbitrase dan Pencarian Fakta. Sidang pertama tentang Jurnal Ilmu Sosial dan Pendidikan yurisdiksi pengadilan berlangsung di ibu kota ASEAN lainnya yang netral pada bulan Januari 2002. Protokol menambahkan Mekanisme Penyelesaian Sengketa ASEAN (DSM) sebagai alternatif. modalitas untuk menyelesaikan perselisihan antar Negara berdasarkan Perjanjian (Pasal 4).

Selain 46 perjanjian tercakup yang berlaku pada saat penerapan DSM pada tahun 1996, sejumlah perjanjian ekonomi lainnya telah ditandatangani dalam beberapa tahun terakhir. Namun demikian, telah berfungsi untuk memperjelas dan membedakan antara dua jenis sengketa, di bawah Perjanjian ASEAN 1987 untuk Mempromosikan dan Melindungi Investasi: Pasal IX berkaitan dengan perselisihan antara Negara atau pihak kontraktor yang tercakup dalam Protokol 1996 tentang Mekanisme Penyelesaian Sengketa, dan perselisihan antara suatu Negara atau pihak kontraktor dan investor nasional atau perusahaan dari Negara lain atau pihak kontraktor berdasarkan Pasal X. Perjanjian biasanya berisi ketentuan yang, jika penyelesaian tidak dapat dicapai melalui konsultasi dan negosiasi, perselisihan akan ditangani sesuai dengan Mekanisme Penyelesaian Sengketa.

Protokol EDSM baru telah direvisi di beberapa bagian dengan tujuan agar sesuai dengan kondisi-kondisi Negara-negara anggota ASEAN saat ini dan lebih jelas, serta sejalan dengan prinsip-prinsip Organisasi Perdagangan Dunia (World Trade Organisasi: WTO) serta dapat menggunakan mekanisme penyelesaian sengketa ASEAN yang baru untuk menyelesaikan sengketa dan memperdagangkan dan mendorong Negara Anggota ASEAN untuk mematuhi kewajiban seperti:

1. Pasal 3 - Konsultasi

(1) Batasi ruang lingkup permintaan. Konsultasikan untuk tidak Termasuk kasus yang tidak (Keluhan NonPelanggaran: NVC) dan situasi apa pun yang timbul (Keluhan situasi: SC) (2) Persyaratan konsultasi yang lebih jelas Ini harus rahasia dan tidak boleh mempengaruhi hak negara anggota dalam prosedur lebih lanjut dan (3) 
memberikan prosedur yang jelas untuk Negara Anggota lain yang menunjukkan bahwa mereka memiliki kepentingan yang jelas dalam meminta partisipasi.

2. Pasal 7 - Kerangka Acuan Panel

(1) Memperpanjang jangka waktu penetapan Kerangka Kerja panel dari aslinya. "Sebelum pembentukan panel" adalah "dalam waktu 20 hari setelah panel dibentuk" dan (2) membatasi ruang lingkup panel untuk memutuskan petisi yang diperlukan untuk keputusan penyelesaian sengketa.

3. Pasal 9 - Fungsi Panel

Tentukan tugas fakultas. Pertimbangan tambahan Mereka memberikan konsultasi rutin dengan negara-negara pesaing dan memberikan kesempatan kepada negaranegara pesaing. Cukup menemukan resolusi yang saling memuaskan.

4. Pasal 10 - Prosedur Panel, Musyawarah dan Temuan

(1) Memperpanjang jangka waktu penyerahan kesimpulan dan rekomendasi kepada SEOM dari "dalam 60 hari" menjadi "dalam 6 bulan" termasuk Jangka waktu dapat diperpanjang dalam kasus khusus dari "tidak lebih dari 10 hari" menjadi "tidak lebih dari 3 bulan". Dan (3) mensyaratkan agar pendapat responden diungkapkan dalam laporan tertulis pada laporan interim panel Keputusan Komite Peninjau.

5. Pasal 11 - Perlakuan Laporan Panel

(1) Tetapkan jangka waktu bagi SEOM untuk menyetujui laporan panel tidak kurang dari 20 hari. Setelah tanggal SEOM menerima laporan dan (2) memperpanjang jangka waktu pengesahan laporan oleh SEOM dari "dalam 30 hari" menjadi "dalam 60 hari.

6. Pasal 13 - Pihak Ketiga

(1) Panjang diperpanjang Pemberitahuan niat SEOM sebelumnya adalah "sebelum pembentukan majelis hakim" menjadi "dalam waktu 10 hari sejak pembentukan majelis hakim" dan (2) menyerahkan hak kepada

Jurnal Ilmu Sosial dan Pendidikan negara anggota pihak ketiga seperti hadir dalam rapat. Pertimbangan para pihak dengan majelis hakim pertama dan kedua menghadirkan keterangan tertulis. Setidaknya sekali sebelum sidang pertama Buat pernyataan lisan kepada panel dan tanggapi pertanyaan dari panel pada sidang pertama. Langsung secara tertulis, dll. Panel dapat memperluas hak kepada pihak ketiga lebih banyak. Tapi pasti begitu Persetujuan sebelumnya dari negara pesaing.

7. Pasal 17 - Pengawasan Pelaksanaan Temuan dan Rekomendasi

menetapkan bahwa yurisdiksi diperlukan. Jangka waktu kepatuhan c Mampu membuat penilaian dan rekomendasi Namun, itu harus menjadi jangka waktu yang wajar untuk mematuhi putusan dan rekomendasi dari panel hakim dan organisasi banding.

8. Pasal 19 - Arbitrase

Memberikan kemampuan untuk mengajukan permohonan. Arbitrase sebagai Alternatif Mekanisme Penyelesaian Sengketa.

9. Pasal 21 - Kerangka Waktu Maksimum Menentukan durasi maksimum proses peradilan dari penunjukan Panel hingga Laporkan sertifikasi Yang tidak boleh melebihi 9 bulan di panel dan 12 bulan di kelas banding Didefinisikan secara spesifik Di mana pihak yang berkonflik tidak boleh memengaruhi hak pihak ketiga.

10. Pasal 22 - Tanggung Jawab Sekretariat menetapkan bahwa Sekretariat memberikan bantuan kepada Negara Anggota ASEAN. Tentang suspensi Sengketa atas permintaan dan dapat memberikan nasihat hukum yang wajar dan sesuai serta bantuan lainnya.

11. Pasal 23 - Prosedur Khusus yang melibatkan Negara-negara anggota ASEAN yang Paling Sedikit Berkembang (1) meningkatkan identifikasi prinsipprinsip pertimbangan khusus untuk keadaan khusus dari negara-negara anggota yang kurang berkembang dan 
melakukan pengendalian yang wajar dalam mengangkat masalah-masalah di bawah proses-proses ini dalam kaitannya dengan Negara-negara Anggota. Negara paling tidak berkembang Dalam menuntut kompensasi atas kerusakan Atau meminta persetujuan untuk menangguhkan pemberian manfaat Dan (2) Presiden SEOM akan mengusulkan metode koordinasi, sikap, konsiliasi dan mediasi. Sendiri untuk membantu para pihak dalam menyelesaikan sengketa Sebelum meminta panel juri, presiden SEOM dapat berkonsultasi dengan sumber mana pun yang dianggapnya tepat, atas kebijakannya.

12. Pasal 26 - Amandemen

Tentukan kondisi dan prosedur amandemen. Ketentuan Protokol Dan untuk memperjelas lampiran, amandemen Protokol tersebut harus disetujui secara tertulis oleh semua Negara Anggota. Amandemen Annex I dapat dilakukan secara berkala oleh Sekretariat ASEAN. Setiap amandemen Annex II, III, dan V harus disetujui oleh SEOM, dan amandemen Annex IV dapat dibuat oleh organisasi banding, yang tunduk pada diskusi dan opini. Disukai oleh SEOM dan Sekretaris Jenderal ASEAN.

13. Pasal 27 - Ketentuan Akhir

Dijadwalkan mulai berlaku pada Semua 10 negara anggota ASEAN telah menginformasikan Sekretaris Jenderal ASEAN telah menyelesaikan prosedur internal yang diperlukan untuk penerapan Protokol ini.

\section{KESIMPULAN}

Mekanisme penyelesaian sengketa yang mungkin akan terjadi dalam proses implementasi protokol ESDM pada sektor ekonomi dan perdagangan internasional harus lebih diperjelas. Perlu dicatat, bahwa usaha ini bukan pekerjaan yang mudah karena untuk membantu membangun kepercayaan Sektor swasta ke dalam berdagang dan berinvestasi satu sama lain melalui mekanisme, Jurnal Ilmu Sosial dan Pendidikan mengesahkan atau membantu memecahkan masalah komersial Negara internasional, terutama dengan dikeluarkannya regulasi atau langkah perdagangan yang tidak sesuai. Pengikatan atau kewajiban yang disepakati dalam amandemen Protokol EDSM yang baru memperkuat mekanisme penyelesaian sengketa Perdagangan ASEAN untuk mencapai efisiensi dengan cara meningkatkannya menjadi praktis, transparan dan jelas.

\section{DAFTAR PUSTAKA}

A.A.A. Ngr. Sri Rahayu Gorda, Kadek Januarsa Adi Sudharma, dan Pipin Carolina BR Barus, "The Analysis of Tendency on Choice of Forum in The Settlement of Dispute of International Trade Among ASEAN Countries", Arena Hukum, Vol. 13, No. 1, 2020.

Acharya, Amitav, constructing a Security community in Southeast Asia: ASEAN and the Problem of Regional Order, London: Routledge, 2001.

Anna G Tevini, Regional Economic Integration and Dispute Settlement in East Asia, New York: Hart Publishing, 2018.

ASEAN Charter 2008

ASEAN Protocol On The Enhanced Dispute Settlement Mechanism

Collin Wong, Venus Kim, dan Affendy Arip, "The impact of ASEAN free trade area on intra-ASEAN manufacturing trade", International Journal of Business and Society Vol, 18, No. 3, 2017.

Dan Jefferson Lopez, "The ASEAN Geography and Its Significance to Its Economic Development", Asia Society Project, 2019.

Departemen Luar Negeri RI, ASEAN Selayang Pandang, Jakarta: Sekretariat Nasional ASEAN, 2010.

Departemen Perdagangan Republik Indonesia, Menuju ASEAN Economic Community 2015, Jakarta: Kemendag, 2013. 
Diane A Desierto dan David J Cohen, ASEAN Law and Regional Integration, 2020.

Farhad Taghizadeh-hesar, et.al., Achieving Energy Security In Asia: Diversification, Integration And Policy Implications, Singapore: World Scientific Publishing Co, 2019.

Framework Agreement on Enhancing ASEAN Economic Coorperation

Ghosh, S. \& Yamarik, dan 2004, “Are preferential trade agreements trade creating? An application of extreme bounds analysis", Journal of International Economics, 2004.

Heri Akhmadi, "Assesment in the Impact of ACFTA of Exports of Indonesian Agricultural Commodity", Journal of Agribusiness and Rural Development Research, Vol. 3, No. 1, 2019.

Hilton Tarnama Putra, Mekanisme Penyelesaian Sengketa di ASEAN: Lembaga dan Proses, Jakarta: Graha Ilmu, 2011.

Imelda Deinla, The Development of the Rule of Law in ASEAN, Cambridge: Cambridge University Press, 2017.

Joel Vander Kooi, "The ASEAN Enhanced Dispute Settlement Mechanism doing it the ASEAN way", New York International Law Review, 2007.

Koesrianti, "Analisa Kekuatan Mengikat Piagam Asean Dan Perkembangan Mekanisme Penyelesaian Sengketa Di Asean", Yuridika, Volume 26 No 1, Januari-April 2011.

Kooi, Joel Vander 2007, "The ASEAN enhanced Dispute Settlemet Mechanism: Doing it the ASEAN Way", New York International Law Review, 20 N.Y. Int'1 L. Rev. 1, hlm. 1-37.

Najjamudin Khairur Rijal, "Tantangan Impelementasi Asean Community: Kasus di Kota Malang", Jurnal Insignia, Vol. 4, No. 1, April 2017, hlm. 55; Sanchita Basu Das, et.al, The ASEAN Economic Community: A Work in Progress, Singapore: Asian Development Bank, 2013.

Jurnal Ilmu Sosial dan Pendidikan
Naldi, G. J, "The ASEAN Protocol on Dispute Settlement Mechanisms: An Appraisal", Journal of International Dispute Settlement, Vol. 1, No. 34, 2015.

Narine, Shaun, Explaining ASEAN: Regionalism in southeast Asia, Lynne Rienner Publishers, Dahai. 2008." State Immunity, China and Its Shifting Position", 7 Chinese J. Int'l L. 307, 2002, hlm.307-333.

Nattapat Limsiritong, "How to Apply the ASEAN Protocol on Enhanced Dispute Settlement Mechanism 2004 to Settle Disputes on the Interpretation of ASEAN Comprehensive Investment Agreement 2009", PSAKU International Journal of Interdisciplinary Research, Vol. 7 No. 2 (July-December 2018).

Natthada Termudomchai, "ASEAN Dispute Settlement Mechanism: a Study of its Ineffectiveness in Resolving Economic Disputes", Assumption University Law Journal, Vol. 7, No. 2, 2016.

Pornchai Danvivathana, "Role of ALA in the current legal issues under the ASEAN Charter", Thailand Law Journal, Volume 13, 2016.

Ralf Emmers, Cooperative Security and the Balance of Power in ASEAN and the $A R F$, London: Routledge, 2017.

Ramcharan, Robin, "ASEAN and Noninterference : A Principle Maintained". Contemporary Southeast Asia, Vol. 22, No.1, 2000, hlm.60-88.

Ross Garnaut, $O$ pen Regionalism and Trade Liberalization: An Asia-Pacific Contribution to the World Trade System, Sydney: Institute of Southeast Asian Studies, 1996.

Rungnapa Adisornmongkon, "The Dispute Settlement Mechanism of ASEAN, Does it work?'”, Assumption University Law Journal, Vol. 7, No. 2559, 2016.

Sanchita Basu Das, Achieving the ASEAN Economic Community 2015: Challenges for Member Countries \& 
Business, Singapore: Institute of South east Asian Studies, 2012.

Simon Chesterman, "Does ASEAN Exist? The Association Of Southeast Asian Nations As An International Legal Person", Public Law \& Legal Theory Research Paper Series Working Paper No. 08-26, 2010 Singapore Year Book Of International Law And Contributors.

Sumaryo Suryokusumo, Studi Kasus Hukum Organisasi Internasional, Bandung: Alumni, 1997. 